\title{
Discourse of psychoactive substance dependents on their discursively constructed image
}

\author{
Discursos de dependentes de substâncias psicoativas sobre sua imagem discursivamente construída \\ Discurso de los dependientes de sustancias psicoactivas sobre su imagen construida discursivamente
}

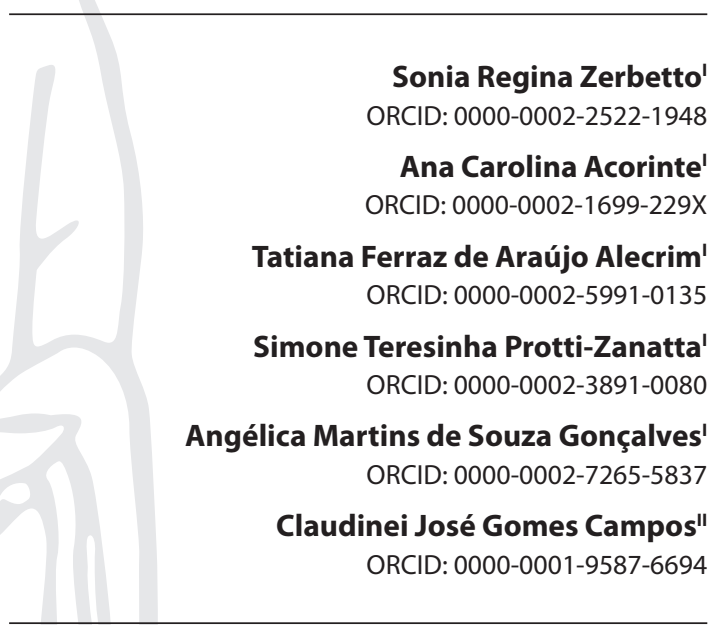

'Universidade Federal de São Carlos. São Carlos, São Paulo, Brazil.

"Universidade Estadual de Campinas. Campinas, São Paulo, Brazil.

How to cite this article: Zerbetto SR, Acorinte AC, Alecrim TFA, Protti-Zanatta ST, Gonçalves MAS, Campos CJG. Discourse of psychoactive substance dependents on their discursively constructed

image. Rev Bras Enferm. 2020;73(1):e20180196. doi: http://dx.doi.org/10.1590/0034-7167-2018-0196

\section{Corresponding Author: \\ Sonia Regina Zerbetto \\ E-mail: szerbetto@ufscar.br}

EDITOR IN CHIEF: Dulce Aparecida Barbosa ASSOCIATE EDITOR: Priscilla Valladares Broca

Submission: $03-31-2018$

Approval: 06-08-2018

\section{ABSTRACT}

Objective: to analyze the discourse of psychoactive substance users undergoing treatment regarding their image of themselves as drug dependent subjects, of other dependents and the social position assumed by them. Method: qualitative study conducted between March and September of 2016 through a semi-structured interview and drawings, based on the theoretical-methodological reference of French Discourse Analysis. Participation of 12 drug dependent subjects undergoing treatment in the service that substitutes the asylum. Results: The images that psychoactive substance dependents have of themselves and of chemically dependent subjects are associated with the image of a negative, diabolical, transgressive, sick and socially excluded individual. Final considerations: The ideological effects of meanings produced by users' discourses reproduce the biological and moral model. Health professionals, including nurses, need to invest in discourses that address the psychosocial model to demythologize this stigmatizing image and modify their work practice.

Descriptors: Substance-Related Disorders; Speech; Mental Health; Drug Users; Psychiatry.

\section{RESUMO}

Objetivo: analisar o discurso do usuário de substâncias psicoativas em tratamento sobre a imagem que ele tem de si mesmo enquanto sujeito dependente de drogas, dos outros dependentes e da posição-social assumida por ele. Método: estudo qualitativo, realizado em março e setembro de 2016, por meio de entrevista semiestruturada e desenhos, baseado no referencial teórico-metodológico da Análise de Discurso de linha francesa. Participaram 12 dependentes de drogas em tratamento no serviço substitutivo ao manicômio.Resultados: As imagens que o dependente de substâncias psicoativas tem de si e do dependente químico estão associadas com a imagem negativa, diabólica, transgressora, de doente e socialmente excluído.Considerações finais: Os efeitos de sentido ideologicamente produzidos pelos discursos dos usuários reproduzem o modelo biológico e moral. Os profissionais de saúde, inclusive o enfermeiro, necessitam investir em discursos que abordem o modelo psicossocial, para desmitificar esta imagem estigmatizante e modificar sua prática no âmbito de seu trabalho. Descritores: Transtornos Relacionados ao Uso de Substâncias; Fala; Saúde Mental; Usuários de Drogas; Psiquiatria.

\section{RESUMEN}

Objetivo: analizar el discurso del consumidor de sustancias psicoactivas en tratamiento sobre la imagen que tiene de símismo como un sujeto dependiente de las drogas, sobre otros dependientes y sobre la posición social asumida por él. Método: investigación cualitativa realizada entre marzo y septiembre de 2016 a través de una entrevista semiestructurada y dibujos basados en la referencia teórico-metodológica de la escuela francesa del Análisis del Discurso. Doce adictos a las drogas fueron tratados en el servicio de sustitución del manicomio.Resultados: las imágenes que los dependientes de sustancias psicoactivas tienen de sí mismos y de los dependientes químicos se asocian con la imagen negativa, diabólica, transgresora, enferma y de una persona socialmente excluida. Consideraciones finales: los efectos de significado producidos ideológicamente por los discursos de los dependientes reproducen el modelo biológico y moral. Los profesionales de la salud, incluidos los enfermeros, deben invertir en discursos que aborden el modelo psicosocial, para desmitificar esta imagen estigmatizante y modificar su práctica en el trabajo. Descriptores: Trastornos Relacionados con Consumo de Sustancias; Habla; Salud Mental; Consumidores de Drogas; Psiquiatría. 


\section{INTRODUCTION}

Dependence on alcohol and other drugs has always been represented in the social imaginary as a problem associated with crime and danger ${ }^{(1-4)}$. This fact reinforces the construction of a collective discourse permeated with stigma and prejudice related to people who consume psychoactive substances ${ }^{(3-4)}$, which in turn, triggers the marginalization and social segregation of this specific population that receives moralistic and stigmatizing denominations, such as marginal and vagabond $d^{(1,5)}$.

Considering such issues, in the social imaginary, dependent people or drug abusers assume social positions assigned to them and can take the place of a sick, transgressive, marginal, vagabond, crazy or dangerous person ${ }^{(1,5)}$.

National studies on social representations of crack from the point of view of dependents undergoing treatment highlight the negative, destructive and diabolical view of this substance, blame only drug users for physical and social damages, and disregard other social, economic, cultural and historical determinants involved in the problematic of drugs in society ${ }^{(2,5)}$.

Given this context, drug users are negatively impacted in their social interactions and daily life, which can lead to sickness, demand treatment and trigger the judicialization mechanism through compulsory hospitalization.

The phenomenon of psychoactive substances is historically permeated by biological or disease, legal and moral paradigms ${ }^{(6)}$. Despite the peculiarities of these models, they are convergent on focusing only on the drug and users, who are understood as sick people, deviant from standards of norms and normality ${ }^{(7)}$, requiring remission of symptoms and the search for the "normal" state of subjects ${ }^{(8)}$.

These models contradict the psychosocial model that values the life history of drug users, their socio-cultural context ${ }^{(7)}$ and recognizes psychic suffering as part of the human condition existence ${ }^{(9)}$. Thus, there is shift from dichotomous and opposing perceptions of health (positive) and disease (negative) to the dialectical relation of reality, in which both are antagonistic and unitary phenomena in the daily experience of human being $s^{(9)}$. The relational conception of illness-cure changes to that of existence-suffering, which demands extended and transdisciplinary care ${ }^{(8)}$.

In view of such considerations, the discourse of psychoactive substance users undergoing treatment is permeated by other discourses, crossed by dominant meanings of the biological or disease, moral, legal and psychosocial models that designate the individuals' image of themselves, of other dependents, and of their subject-position.

The literature review has gaps in studies exploring such perceptions discursively. Thus, the analysis and interpretation of the discourse of psychoactive substance users treated at the Center for Psychosocial Care - Alcohol and Drugs (Portuguese acronym: CAPS AD) will allow to understand them in their constitution as subjects of discourse. Furthermore, understanding the historical conditions of their discourse and the ideologies that pervade it can help individuals to change social positions that degrade them and not recognize them as citizens of and with rights.

\section{OBJECTIVE}

To analyze the discourse of psychoactive substance users undergoing treatment on the image they have of themselves as drug dependent subjects, of other dependents and the social position assumed by them.

\section{METHOD}

\section{Ethical aspects}

All ethical aspects of research involving human beings recommended by Resolution number 466/2012 were respected. This study was approved by the Research Ethics Committee and recognized by the National Commission of Ethics in Research of the National Health Council (Portuguese acronym: CONEP-CNS). All participants signed the Informed Consent form.

\section{Theoretical reference}

The theoretical-methodological reference was the French Discourse Analysis (DA) based on the theoretical constructs of Michel Pêcheux that seeks to "understand how symbolic objects produce meanings"(10).

Through the Discourse, are understood the meanings between speakers, because the language relations constitute relations of subjects and effects of meanings, hence the DA is the analysis of these effects of meaning ${ }^{(10-11)}$.

The Discourse is determined by the ideology materialized in the ideological signs and positions influencing the image that subjects apprehend of themselves in the socio-historical context ${ }^{(10)}$. Subjects in the DA do not have discursive processes originated in themselves, but in the discursive formation with which they identify when occupying a discursive place that is determinant of and in their speech $^{(10)}$. Discursive formation (DF) is a set of statements marked by the same regularities and rules of formation influenced by the ideological positions assumed in a given socio-historical context, which determines what can and should be said(10-11).

According to the concepts of $\mathrm{DA}^{(10)}$, in their discourse, chemically dependent subjects are dominated and fragmented. Therefore, they speak from an ideology in their discursive manifestation, which makes it possible to identify them (including their subjectposition) with their dominant discursive formation. The subject results from several other discourses that may involve psychosocial, biological or disease, moral and legal paradigms.

\section{Type of study}

Descriptive, qualitative study based on the French matrix theoretical-methodological reference of Discourse Analysis.

\section{Methodological procedures}

\section{Scenario of the study}

This study was conducted at the Center for Psychosocial Care - Alcohol and Drugs (Portuguese acronym: CAPS AD II) of a city in 
the inlands of the state of São Paulo, which serves and cares for people who abuse or are dependent on psychoactive substances.

\section{Data source}

The selection of participants was through a technique of intentional sampling of 12 users of psychoactive substances in intensive (daily follow-up) and semi-intensive follow-up (frequent follow-up, non-daily) in the CAPS AD. These users were nominated by the health professionals of this specialized service. Of the 21 individuals identified, nine denied participation in the study.

The inclusion criteria consisted of age greater than or equal to 18 years, teetotal or not, with or without psychiatric comorbidities. The exclusion criterion was to be intoxicated and in a psychotic outbreak during the interview.

\section{Collection and organization of data}

Data were collected through a semi-structured interview ${ }^{(12)}$ and projective technique in the form of drawings ${ }^{(13)}$.

Interviews were performed and audio-recorded in the premises of CAPS AD between May and September 2016 and had an average duration of one hour. They were used for the characterization of participants, included personal identification data and the following guiding questions: What is your view of the person who is dependent on drugs? How do you perceive yourself as a psychoactive substance dependent person in treatment? How do you perceive your treatment?

The projective technique in the form of a drawing was used to help construct the image of the psychoactive substance dependent subject $^{(13)}$. The participant was asked to make a drawing guided by the phrase: Draw how you see yourself as a psychoactive substance dependent person. Make comments about your drawing.

Participants of the study were identified with the initials "SD", corresponding to Subject of Discourse, followed by a sequential numbering related to the order of interviews, such as: SD1, that is, Subject of Discourse, number one.

The discursive sequences with sentences of the speech of Subjects of Discourse were represented by initials "ds", followed by the numbering of their sequence in the discursive group (Example: ds4). Discursive excerpts were identified by the word "Excerpt" followed by the letter " $n$ " corresponding to the word number, followed by the numbering of its sequence (for example: Excerpt n.1).

\section{Data analysis}

The analysis was based on the assumptions of DA and its analytical method ${ }^{(11-12)}$, in which the aim is to understand how symbolic objects (in this case, interview statements and the image of drawings) produce meanings and how they are imbued with significance for and by subjects.

In this analytical process, through interviews and drawings, it was possible to perceive the opacity of language and the meanings determined by historicity as interpreted by researchers. The idea was to capture the subject constituted by ideology and historicity, and the manifesto of the unconscious ${ }^{(10)}$.
Thus, the discourse of CAPS AD users allowed the production of effects of meaning on the dependence on alcohol and other drugs for them and their discursively constructed image. The DA analytical process involved three steps.

In the first step, called the passage from the linguistic surface to the object of the discourse, the interviews were transcribed verbatim, including linguistic resources ${ }^{(10,14)}$. In this moment of transition, we searched for traces, clues, hints, the said and the unsaid, through polysemy and metaphors ${ }^{(10,14)}$. The regularities of these linguistic marks in the statements corresponded to the subjectivity of interviewees and expressed preconstructed meanings that exist in the memory of the discourse of society ${ }^{(10)}$.

The operationalization of this step required reading the discourses repeatedly, going from the apparent obvious to the understanding of mechanisms of meaning production used by interviewees, and were constructed the contours of the Discursive Formation (DF) ${ }^{(10)}$. The "discursive excerpts" were established and the different meanings for each subject of the discourse were understood, as well as the articulation between what is said and the social and discursive position of the speaker.

The second step involved the passage from the discursive object to the discursive process, and the discursive sequences (sentences) were analyzed. The DFs were related to the ideological formation by structuring the speech of the statement with the speech crystallized in society, the place where the ideology permeates and is concretized in the discursivity ${ }^{(10,14)}$.

In the third step, the discursive process was transformed into ideological and imaginary formation. The statements of all interviewees were grouped into discursive groups that constituted a common ideology from where the DF emerges. This step included the process of description, discussion and interpretation of results, i.e. the meanings produced, the analytical devices and the conditions that determined such formation ${ }^{(10,14)}$.

When addressing the ideological formation in the discourse, was described and discussed the imaginary formation of the subjects analyzed ${ }^{(10)}$. The images resulting from projections of the perception of psychoactive substance users of their image as chemically dependent people were also understood.

The analysis of data revealed two discursive sections: 1) The image that dependents on psychoactive substances in treatment have of themselves and of the chemically dependent person; 2) The discourse of society about the subject dependent on psychoactive substances (PSs) from the perception of users. In this article, only the first discursive section was described and interpreted.

\section{RESULTS}

The Discursive Section addressed the effects of meaning ideologically produced about the image that subjects have of themselves while dependent on PSs, and of the drug dependent person through the statements and drawings.

\section{Discourse of being diabolical and evil}

Excerpts number 1 and 2 pointed to the discursive sequences $\mathrm{ds} 1, \mathrm{ds} 2$ and ds 3 of enunciators who expressed meanings of the same Discursive Formation. They related the image of psychoactive 
substance dependents and of themselves to the negative and evil image of a suffering being because of their connection with the devil's power.

Excerpt n.1: [...] my view is that chemically dependent people are all suffering (sd1), you know, Bro [...] they're all people used by the demon (ds2). (SD8)

Excerpt n.2: You are the slave of the devil (ds3). [...] my life was a lighter, a pipe, a rock and a cigarette (sd4), that's it, you know?(SD1)

The evil and diabolical image was also reinforced by drawing 1 of the Subject of Discourse 1, in which the speaker drew himself with two horns.

In ds 4 of excerpt n. 2, Subject of Discourse 1 compared his life to the drug and accessories used to smoke crack by reinforcing the meaning that the life of a chemically dependent person and his own life are limited to the accessories used to smoke that substance.

In sd1 of excerpt n.1, the signifier "chemically dependent" was related to the person who depends on the psychoactive substance. This signifier was related to other discourses, such as the domain of the biological or disease model.

\section{Discourse of being trash}

In excerpt n. 4 of SD3, the ds9 demonstrated the constructed image of the psychoactive substance dependent person as a useless and dirty person excluded from social life, when the subject of discourse compared himself to a trash can.

Excerpt n. 4: A trash can (ds9). No comments. (SD3)

\section{Discourse of being a sick person}

Continuing the analytical process, the words of discursive sequences 10 and 11 of SD3 expressed that dependence is a disease. The Subject of Discourse 11 reinforced the speech of the same Discursive Formation, that is, the subject-position of a patient assumed by him.

Excerpt n.5: Well, that's a disease (sd10). [...] So, my view is that we are all sick people (ds11). (SD3)

Enunciators SD3 and SD6 reported that chemical dependence is an incurable disease, according to discursive sequences 14 and 15 .

Excerpt n.5: [...] we want the get cured, but we can't (ds14)! It's difficult. (SD3)

Excerpt n.6: [...] that it's [dependence] for the rest of life (ds15). (SD6)

\section{Discourse of being deviant and transgressor}

Excerpts $n .7$ and $n .8$ emphasized effects of meanings regarding inappropriate social behavior and transgressive attitudes towards the moral rules of society, such as carelessness with personal hygiene (ds17 and ds20), lack of manners during meals (ds18) and character flaws, recognized in the act of asking for money on the street and lying (ds21 and ds22). The speakers compared themselves to wild nocturnal animals such as the leopard, which goes hunting at night and at dusk. A person who eats like an animal because he devours the food.

Excerpt n.7: That causes trouble, gets up late at night [...] Doesn't shower (ds17), and eats food like a leopard (ds18). (SD4)

Excerpt n.8: I didn't take a shower, I'd go for weeks without a shower (ds20) ... I asked for money on the street (ds21), they gave me ... I lied (ds22). (SD2)

\section{Discourse of being weak}

The Subject of Discourse 6 expressed an image of being weak when assuming the inability to control his compulsive behavior toward drug use.

Excerpt n.9: My view is, I think it's ... is a weakness that you can't control (ds22). When you see, you're already there [drug den]. You're already smoking it (ds23). (SD6)

\section{Discourse of being excluded from society}

The effects of meanings in excerpt $\mathrm{n} .10$ stressed the social exclusion of the drug addict through the "excluded" and "detached" signifiers.

Excerpt n.10: Here is society and the dependent excluded from society, detached from society (ds24). (SD8)

\section{DISCUSSION}

In excerpts $\mathrm{n} .1$ and n.2, both ds2 ("chemically dependent people are all used by the demon") and ds3 ("You are the slave of the devil") have expressed the meaning that the "devil" represents the drug as something evil and therefore, personalized in the demonic figure. In statement ds3, the chemically dependent person is expressed as dominated and subjected to the will of the drug, and consequently deprived of freedom. The drug uses people, enslaves them and imprisons them.

These data corroborate studies based on the theoretical reference of social representations of psychoactive substance users in treatment, who express negative views of themselves and recognize themselves as suffering, distressed and miserable people ${ }^{(6)}$. The drug is considered damned, associated with the devil and the power to destroy the life of users ${ }^{(5)}$. A study that analyzed the ideology permeating journalistic news on crack indicates that this substance enslaves the human being ${ }^{(15)}$.

Both ds2 and ds 3 carried marks and traces of religious discourse. When reflecting on the strict conditions under which the respective discourses were produced, subjects were affected by their cultural and religious history. As the enunciators are evangelical Christians who relied on their religious institutions to treat chemical addiction, it was possible to think about their discursive practices. According to the DA, in all the saying there is an already said (interdiscourse), that is, every discourse passes through another discourse inserted in the discursive memory of the enunciator, although in an unconscious way ${ }^{(10)}$. The devilish view associated with drug use has been reinforced and condemned 
by Christian religions, and this aspect of the malignancy of psychoactive substances has been anchored in religious knowledge, which associates the drug with the devil's image ${ }^{(5)}$.

Historically, in the Middle Ages, the use of hallucinogenic plants was forbidden by the Catholic Church, because they were used in pagan rituals and considered demonic. The only drug allowed was alcohol, that is, wine was used in Catholic rituals ${ }^{(5)}$, which continues nowadays. These sayings produce meanings that refer to the social imaginary that the drug dependent is a diabolical person who deserves to suffer in hell.

The Discursive Formation that chemically dependent people are diabolical was reinforced by the drawing of SD1, in which he drew himself with two horns. In the historical period of the ninth century after Christ with domination of the Catholic church and the attempt to eliminate paganism, this institution appropriated from the iconography of Satan represented by the image of the Greek God Pan of classical mythology that has horns, goat legs and a trident ${ }^{(16-17)}$.

The ds4 ("my life was a lighter, a pipe, a rock and a cigarette") demonstrated that these accessories promote heating through the fire to burn the rock. Thus, the lighter produces fire that heats the pipe, which heats the rock. Therefore, signifiers related to the warm environment that in turn refers to hell.

That signifies the life of chemically dependent people is hell, where crack imprisoned and enslaved them. These data corroborate the literature, in which is indicated that the negative, harmful and domineering effects attributed to crack by consumers of this substance allow their passive and conformist attitude, where they recognize themselves as victims and unable to make decisions in the face of this situation ${ }^{(5)}$. The words of enunciators of this study permeated the non-said belief in the power attributed to the drug that subjugates and withdraws the autonomy of human beings by making them passive and impotent in the situation of dependence ${ }^{(5)}$. This conception ratifies the medical and disease discourse advocated by abstinence as the only therapeutic alternative ${ }^{(5,17)}$.

In ds1 of excerpt n.1 ("my view is that chemically dependent people are all suffering"), the signifier "chemically dependent"was expressed in the language of the enunciator derived from his discursive memory related to the biological and disease paradigm and paraphrases the language of medical discourse. For the DA, the subject is affected by the unconscious in this process, but the ideology permeates any discursive manifestation and allows an identification with the discursive formation that dominates it ${ }^{(10)}$.

The biological paradigm inserts the psychoactive substance dependent person into the pathological picture of disease or mental disorder resulting from this consumption. Faced with this explanatory model for dependence, treatment is focused on the signs and symptoms that must be eliminated. The goal is to cure mainly through medication, abstinence and behavior change.

In this model, the dependence determinant is organic and requires a basic therapeutic intervention at pharmacological level. The person is recognized as sick and the intervention is centered in his/her organism. From this viewpoint, these people are isolated from their family and social environment and excluded from participation in their treatment and care $^{(8)}$.

Most studies that address social representations of chemical dependence as a disease highlight psychoactive substances as the main cause $\mathrm{e}^{(5,18-19)}$. Hence, the goal of treatment is total abstinence.
The ds9 ("a trash can") offered the understanding of effects of meanings that psychoactive substance dependent subjects feel like trash, that is, a receptacle that collects garbage; receiver of things/objects that should be thrown away or contain useless things. On the other hand, such a discursive sequence revealed the unspoken, in that case, the enunciator feels like rubbish, someone who can be disregarded, thrown away or excluded for being "something" useless.

A study on the social meanings of drug users emphasizes that when they are represented in a negative way, they are objectified both by themselves and by society in an inanimate object and reduced to the condition of the drug ${ }^{(6)}$ and not to a citizen-being, subject of rights and duties with singularity and subjectivity. The negative perception expressed by SD3 in ds 9 can influence and harm a person's self-image by making them feel with low selfesteem and intensify the process of self-stigmatization. Thus, the person adopts a passive, shameful and self-devaluing behavior, and does not perform his/her social roles, which makes recovery and rehabilitation difficult ${ }^{(20)}$.

The discourses pointed to effects of meaning in which the dependent is reported as the macula of capitalist society. The literature corroborates such findings by reinforcing the degrading view of drug users, who internalize negative stereotypes associated with psychoactive substance dependence and express feelings of shame or inferiority. Such an attitude triggers the low social hierarchical status $(4,6,19,21)$.

The transformation of such social imaginaries demands the implementation of strategies that problematize and democratize knowledge and practices without using excluding moral models and practices as reference, but instead, that value the life history of these people ${ }^{(4)}$. Strategies should be created to raise society's responsibility and awareness for this issue ${ }^{(4)}$.

The discursive sequences of enunciators expressed their sick and chemically dependent subject-position as incurable and demonstrated that they resorted to the evocative language of their discursive memory related to the biological paradigm by paraphrasing "sickness", "sick", and "cure'"'In the theoretical reference of DA, the individual is dominated and fragmented. The ideology permeates their discursive manifestation and allows their identification with the discursive formation that dominates them ${ }^{(10)}$.

The materialization of signifiers "sickness" and "cure" expressed the dependence on psychoactive substances according to the medical model, in which it is understood as a progressive pathology with organic manifestations (both physical and mental) requiring medical treatment ${ }^{(22)}$. In this model, the determinant of chemical dependence is organic (heredity and/or neurochemical dysfunctions) and the person who consumes drugs is recognized as having a disease (thereby becoming sick), for which cure must be found ${ }^{(8,22-23)}$. The absence of disease means health. The syndrome of dependence on psychoactive substances included in this model is a set of signs and symptoms that determines a chronic and recurrent disease in which there is a compulsive and progressive behavior of substance consumption and recognition of its aspect of continuity, gravity and lack of cure ${ }^{(22)}$. In the biological conception of disease, dependence is conceived as a chronic, "inborn" disease of the organism that lasts for a lifetime, but can be treated and controlled with the reduction of symptoms, 
although recurrent ${ }^{(24)}$. These facts often justify the impediment of a person's decision and willingness to stop using the drug ${ }^{(25)}$.

In ds15, enunciator SD6 gave signs of silencing, that is, he spoke something so that other meanings did not appear, for example, when the signifier "it" corresponds to "dependence". The Subject of Discourse 6 used a certain term (in this case, "it") to construct his speech by erasing or silencing another signifier ("dependence"). The silence policy in its form of constitutive silence allows the subject to say $X$ in order not to say $Y$. In the production of "a given statement, the subject erases other possible meanings that may be undesirable in a given discursive situation"(26). By silencing the significant, "dependence" that will last for a lifetime, the speaker has managed to distance himself from the feeling of closeness and permanence of the disease in its vital trajectory.

The discursive sequences that addressed the interviewers' inadequate behaviors according to the moral and behavioral values of contemporary society, expressed meanings of the same Discursive Formation. The statements related the image of substance-dependent people and of themselves to the image of deviant, transgressive beings, who "cause trouble" to society, because they disturb the sleep of others, "wake up at late at night", "ask for money on the street and lie". These are hegemonic and dominant imaginary formations in society and these stereotypes were internalized by users, influence the formation of their self-image ${ }^{(6)}$ and associate them with "vagabond", "deviant", and "transgressor" individuals. The evidence has shown the use of metaphors, that is, figures of language producing figurative meanings through implicit comparisons between the drug dependent and an animal.

In excerpt n.7, the subject of discourse compared himself and the psychoactive substance dependent person to life situations of animals with nocturnal habits, because the dependent person leaves at night, searches for the substance and uses it in a voracious way.

The excerpt $n .9$ pointed the frailty of dependent people for not controlling their drug use, which signaled the Discursive Formation of the moral model. "This model emphasizes that individuals are considered responsible for both the onset and development of the problem and solutions, and therefore, the belief is that they only need motivation"(22:678) from within to reach abstinence. The main limitation of the moral model is the feeling of guilt generated in the person, who assumes responsibility for the problem and does not have motivation to change the compulsive behavior ${ }^{(22,27)}$.

Excerpts n.7 and n.9 pointed other signs of silencing, when subjects used a certain term in a given discursive situation to construct their speech, such as "there", and deleted the significant "drug den", which could produce undesirable meanings. These other meanings are those that one wishes to avoid, because they belong to other discursive formations, such as dangerousness, criminality and transgression. According to the DA, the silencing is performed by the mechanism of replacing one statement by others. The silence invades the said, so that the unspoken is meant ${ }^{(10)}$.

The ds24 pointed to the "excluded" and "detached" signifiers, which reinforced the Discursive Formation of social exclusion of people dependent on psychoactive substance. Studies on the relationship between drug dependence and social exclusion emphasize the social ideology that such consumers are unproductive subjects in the dimensions of work and social relationships. They reinforce the stereotyped view of people who do not work, do not have family ties and housing, and are deprived of rights ${ }^{(4)}$. Studies that discuss the theme of human rights and chemically dependent people report that this population experiences a situation of segregation, social prejudice, and the difference of rights between them and non-users of PSs ${ }^{(28-29)}$.

\section{Limitations of the study}

The limitation of this study was the fact that the understanding of statements derived from discourses of psychoactive substances users and not from health professionals of the CAPS AD investigated. However, the use of Discourse Analysis constituted the originality of this study.

\section{Contributions to the area of Nursing, health or public policy}

The apprehension of the effects of meaning on the discursively constructed image of chemically dependent subjects allowed the problematization of this social phenomenon, not only in the microsocial space of the CAPS AD, but in the macrosocial of public policies of alcohol and other drugs and harm reduction. Despite advances in the Psychiatric Reform process that involves changes in care according to the new theoretical and practical norms of the psychosocial model, in the imaginary of CAPS AD users, remains a discursive memory permeated by other discourses of traditional models.

This study subsidizes the reflection of health professionals of services that replace the asylum model, especially nursing professionals, about their knowledge and practices that can be permeated by contrary models to the psychosocial model and be influencing users ideologically.

\section{FINAL CONSIDERATIONS}

The results demonstrated that the image of psychoactive substance dependents and of themselves is still associated with the negative, evil and diabolic image reinforced by the Christian Discursive Formation. However, the enunciators used language derived from their discursive memories related to the biological/ disease and moral paradigm.

The subjects of discourse expressed meanings related to the image of psychoactive substance dependents and of themselves of deviant, transgressive and vagabond human beings, thereby reinforcing the Discursive Formation of social exclusion and their stigmatization process.

The results showed that users of the studied CAPS AD still reproduce words from the biological and moral model in their discourses. This fact demonstrates that CAPS AD professionals, including specialist mental health nurses, need to invest in other discourses that approach the psychosocial model, demystify this stigmatizing image and modify their practice in the scope of their work.

\section{FUNDING}

This study was financed in part by the Coordenação de Aperfeiçoamento de Pessoal de Nível Superior - Brasil (CAPES) - Finance Code 001. 


\section{REFERENCES}

1. Acioli Neto ML, Santos MFS. Alterity and identity refusal: the construction of the image of the crack user. Paidéia. 2014;24(59):389-96. doi: $10.1590 / 1982-43272459201413$

2. Medeiros KT, Maciel SC, Sousa PF, Vieira GLS. Vivências e representações sobre o crack: um estudo com mulheres usuárias. Psico-USF. 2015;20(3):517-28. doi: 10.1590/1413-82712015200313

3. Rodrigues DRSR, Conceição MIG, lunes ALS. Representações sociais do crack na mídia. Psic Teor Pesq. 2015;31(1):115-23. doi: 10.1590/0102-37722015010994115123

4. Bard ND, Antunes B, Roos CM, Olschowsky A, Pinho LB. Stigma and prejudice: the experience of crack users. Rev Latino-Am Enfermagem. 2016;24:e2680. doi: 10.1590/1518-8345.0852.2680

5. Melo JRF, Maciel SC. Crack social representations elaborated by users under treatment. Psicol Estud. 2015;20(1):23-32. doi: 10.4025/ psicolestud.v20i1.23989

6. Melo JRF, Maciel SC. Drug user's social representation in the perspective of chemical dependent. Psicol Ciênc Prof. 2016;36(1):76-87. doi: $10.1590 / 1982-3703000882014$

7. Medeiros R. Social construction of drugs and crack and the institutional responses and therapeutic approaches. Saúde Soc. 2014;23(1):10517. doi: 10.1590/S0104-12902014000100008

8. Costa-Rosa A. O modo psicossocial: um paradigma das práticas substitutivas ao modo asilar In: Amarante P, organizador. Ensaios: subjetividade, saúde mental, sociedade. Rio de Janeiro: Fiocruz; 2012. p. 140-68.

9. Basaglia F. Scritti Il (1968-1980): dall'apertura del manicomio alla nuova legge sull'assistenza psichiatrica. Torino: Giulio Eunaudi; 1982.

10. Orlandi EP. Análise de discurso: principio e procedimentos. 11 a ed. Campinas: Pontes Editores; 2013.

11. Pêcheux M. Discurso: estrutura ou acontecimento. 7aed. Campinas: Pontes; 2015.

12. Minayo MCS. O desafio do conhecimento: pesquisa qualitativa em saúde. 14ª ed. São Paulo: HUCITEC; 2014.

13. Trinca W. Investigação clínica da personalidade: o desenho livre como estímulo da percepção temática. $2^{\text {a }}$ ed. São Paulo: EPU; 1987.

14. Gomes AMT. From speech to ideological and imaginary formations:a proposal for discourse analysis based on Pêcheux and Orlandi. Rev Enferm UERJ [Internet]. 2007 [cited 2017 Feb 28];15(4):555-62. Available from: http://www.revenf.bvs.br/pdf/reuerj/v15n4/v15n4a13.pdf

15. Romanini M, Roso A. Media and crack: promoting health or reinforcing relations of domination? Psicol Ciênc Prof. 2012;32(1):82-97. doi: $10.1590 /$ S1414-98932012000100007

16. Menon MC. O diabo: um personagem multifacetado. Línguas e Letras. 2008;spe:217-27. doi: 10.5935/rl\&l.v1i1.1318

17. Mota LA. Dependência química: problema biológico, psicológico ou social? São Paulo: Paulus; 2007.

18. Vargas D, Bittencourt MN, Rocha FM, Oliveira MAF. Social representation from nurses from psychosocial care centers for alcohol and drugs (CAPS AD), about the chemical dependent. Esc Anna Nery. 2013;17(2):242-8. doi: 10.1590/S1414-81452013000200006

19. Silva SED, Padilha MI, Oliveira JMMB, Araújo JS, Barata IM, Cunha NMF et al. Dependente sim, viciado não: representações de dependentes químicos. Enferm Foco. 2014;5(1/2):17-20. doi: 10.21675/2357-707X.2014.v5.n1/2.598

20. Rocha FL. Direito biomédico, neurociências e psiquiatria: aspectos teóricos e práticos - doença mental estigma. Percurso Acadêmico. 2013;3(5):145-55. doi: 10.5752/P.2236-0603.2013v3n5p129-142

21. Mora-Ríos J, Ortega-Ortega M, Medina-Mora ME. Addiction-related stigma and discrimination: a qualitative study in treatment centers in Mexico City. Subst Use Misuse. 2016;52(5):594-603. doi: 10.1080/10826084.2016.1245744

22. Pillon SC, Luis MAV. Explanatory models for alcohol and drugs use and the nursing practice. Rev. Latino-Am. Enfermagem. 2004;12(4):67682. doi: 10.1590/S0104-11692004000400014

23. Schneider DR, Lima DS. Implicações dos modelos de atenção à dependência de álcool e outras drogas na rede básica em saúde. Psico [Internet]. 2011 [cited 2017 Mar 03]; 42(2):168-78. Available from: http://revistaseletronicas.pucrs.br/revistapsico/ojs/index.php/revistapsico/article/view/7153

24. Aguilar LR, Pillon SC. Percepción de tentaciones de uso de drogas en personas que reciben tratamiento. Rev Latino-Am Enfermagem. 2005;13(spe):790-7. doi: 10.1590/S0104-11692005000700005

25. Halpern EE, Leite LMC. Representations on patient illness and cure at the Chemical Dependency Center of the Central Navy Hospital. Ciênc Saúde Colet. 2012;17(4):1079-89. doi: 10.1590/S1413-81232012000400029

26. Orlandi EP. As formas do silêncio: no movimento dos sentidos. 6a ed. Campinas: Ed. UNICAMP; 2007.

27. Marlatt GA. Determinantes situacionais da recaída e intervenções de treinamento de habilidades. In: Marlatt GA, Gordon JR, editores. Prevenção recaída. Porto Alegre: Artes Médicas; 1993. p. 64-97.

28. Ventura CAA, Mendes IAC, Trevizan MA, Rodrigues DP. Human rights of drug users according to health professionals in Brazil. Nurs Ethics. 2013;20(2):158-67. doi: 10.1177/0969733012452681

29. Ventura CAA, Santos JC, Mendes IAC, Trevizan MA. The perception of drug users about their human rights. Arch Psychiatr Nurs. 2014;28(6):372-6. doi: 10.1016/j.apnu.2014.08.009 